\title{
In-House Training of Supervisory Library Assistants in a Large Academic Library
}

The need for in-house supervisory programs is presented as are experiences of a program undertaken at one institution. The program has proven to be a successful tool for improving the skills of supervisors. The first year's experiences also underscored the need to explain the program's goals to staff at the beginning.

$\mathrm{T}_{\mathrm{H}}$ SUBJECT OF SUPERVISORY TRAINING for libraries is one that seems to be largely neglected in both library literature and library practice. There are many articles on the training of library assistants but these deal with the technical aspects of librarianship such as book ordering and processing, circulation routines, filing, indexing, etc. Even librarians with exposure to classes in library administration at the graduate level are often inadequately prepared for the myriad of personnel problems that inevitably accompany the supervisory role into which many are thrust.

In general, attitudes toward management and the supervision of employees have changed during the past few years to reflect a more complete integration of personal and organizational goals. We have progressed from the impersonal mechanistic approach of the early 1900 s, through the humanitarian approach of the 1930s that stressed employee happiness, to the present day systems approach that views personal and organizational

Betty Jo Mitchell is associate director of University Libraries, California State University, Northridge, California. needs as interrelated and mutually significant. This attitude places upon supervisors the difficult task of interpreting the needs of both the employee and the organization and of integrating them for the purpose of achieving predetermined goals. In this regard, the task of library supervisors is no different from that of management personnel in other types of organizations.

In large libraries where a librarian may be responsible for several jobtrained library assistants who serve as supervisors for clerical personnel and student assistants, the problem of supervision is compounded; not only must the librarian adhere to sound supervisory practices, he must also see to it that the library assistants employ similar techniques. In institutions where tenure regulations apply to clerical personnel and where grievance procedures demand a carefully constructed case against an employee prior to dismissal, supervisory training becomes essential. Not only must supervisors learn to spot trouble areas early, they must also learn to work with people in order to help them to improve their areas of weakness. If efforts in this direction fail, they must learn 
how to properly prepare their case for dismissal.

At California State University, Northridge, tenure is granted to clerical employees after one year. During that first year, written evaluations are made at four, six, and eight months. Close supervision is required during that time in order that proper attention may be given to potential problem areas and to the documentation of these problems in such a way as to lend support against any grievance action that might occur as the result of the denial of tenure, should that become necessary. In times of rapidly growing staffs when the major problem was that of training large numbers of newly hired clerks in the technical aspects of library tasks, little time remained for attention to individual employee attitudes and productivity. However, when budget reductions began to cut seriously into staffing for clerical and student assistants, the quality of library personnel became increasingly important; the work load remained about the same but there were fewer employees to carry it. Those who remained had to increase their efficiency and thus their productivity. In order to assist the supervisors with such problems as personnel selection, evaluation and motivation, a series of training sessions was planned to include all library assistants who supervised other clerical personnel or a substantial number of student assistants. The following is a discussion of how the program was developed including some of the problems associated with it. Hopefully, it will be of some assistance to others who are encountering similar difficulties.

A literature search uncovered so much material on supervision, organization, human relations, and all aspects of administration and management that it was difficult to know where to begin. After examining a large number of books dealing with a variety of approaches, we decided to begin the program with the portions of Douglas McGregor's The Human Side of Enterprise that discusses two opposing managerial theories which he calls "Theory X" and "Theory Y." ${ }^{1}$ Theory $\mathrm{X}$ asserts that:

(1) The average human being has an inherent dislike of work and will avoid it if he can.

(2) Because of this human characteristic of dislike of work, most people must be coerced, controlled, directed, threatened with punishment to get them to put forth adequate effort toward the achievement of organizational objectives.

(3) The average human being prefers to be directed, wishes to avoid responsibilities, has relatively little ambition, wants security above all.

Conversely, Theory $\mathrm{Y}$ insists that:

(1) The expenditure of physical and mental effort in work is as natural as play or rest.

(2) External control and the threat of punishment are not the only means for bringing about effort toward organizational objectives. Man will exercise self-direction and self-control in the service of objectives to which he is committed.

(3) Commitment to objectives is a function of the rewards associated with their achievement.

(4) The average human being learns, under proper conditions, not only to accept but to seek responsibility.

(5) The capacity to exercise a relatively high degree of imagination, ingenuity, and creativity in the solution of organizational problems is widely, not narrowly, distributed in the population.

(6) Under the conditions of modern industrial life, the intellectual potentialities of the average human being are only partially utilized.

The participants read the two chapters on Theories $\mathrm{X}$ and $\mathrm{Y}$ before coming to the first session; this provided the framework for the discussions that fol- 
lowed. During the first meetings people were reluctant to voice their opinions. In some cases they were strangers to each other due to the fact that the staff outgrew the library building several years ago and the technical services departments were moved to another building some distance away. The supervisors felt unsure of themselves and their ideas; it was necessary to ask questions and then call upon individuals to answer. Soon, however, they began to feel more comfortable with each other; they even argued with each other occasionally.

To many, Theory $\mathrm{Y}$ was an entirely new concept. Some accepted the idea readily; some accepted it reluctantly after much discussion. Most felt that it needed to be modified somewhat to admit that the Theory $\mathrm{Y}$ approach is not effective with every individual. An article was discovered entitled "Beyond Theory Y" which stated that an effective organization must be designed to fit its tasks and its people, not to satisfy some universal theory. ${ }^{2}$ They found this to be an acceptable compromise of the two theories. We read other writers' comments on Theories $\mathrm{X}$ and $\mathrm{Y}$ including Robert Townsend's remarks in a humorous book entitled Up The Organization. ${ }^{3}$ All agreed that supervisors need to learn how to motivate their staff. From the discussions of the group emerged the next topic to be explored, that of motivation.

We began by studying a chapter from Maxine Bishop's Dynamic Supervision entitled "A Further Look at Motivation." 4 This chapter discussed not only McGregor's Theory X and Theory Y, but several other theories as well, including those of Frederick Herzberg who has written a fascinating book entitled Work and The Nature of Man. ${ }^{5}$ Herzberg believes that the factors necessary to happiness on the job are not the same elements necessary to prevent unhappiness. Those factors leading to happiness he calls "Motivators" and they include achievement, recognition for achievement, the work itself, responsibility, advancement, possibility of growth. The factors that are necessary to prevent unhappiness he calls "Hygiene or Maintenance factors" and they include supervision, company policy and administration, working conditions, interpersonal relations with peers, subordinates and supervisors, status, job security, salary, personal life. Attention to these "Maintenance" factors, he believes, may keep an employee from being unhappy with his job, but in order to make him happy with it you must also provide adequately for the "Motivators" to be satisfied. An excellent film is available in which Herzberg explains these factors in detail; it is entitled Motivation Thru Job Enrichment. ${ }^{6}$

From this point on, a variety of questions were raised, providing the content for future meetings. How can I go about the interviewing process in such a way as to select the best possible candidates? How can I learn to motivate people whose backgrounds are widely different from my own? How can I learn to write proper performance evaluations? How can I deal with the situation when I am trying to follow good management practices but my department head will not back me up? How can I better organize the work of my own section?

We provided information on these questions as they came up, and as a result the following materials and programs emerged:

(1) Richard Magee's article "The Employment Interview-Techniques of Questioning" 7 was used as was Frank Gray's "How to Size Up People." articles provided us with information on techniques for selecting the best candidate for the job.

(2) The campus coordinator of the Educational Opportunities Program spoke to the group about the kinds of conscious and unconscious prejudices 
that minorities meet on the job. Minority members of our own staff spoke on the same subject, and we ordered copies of a booklet entitled Prejudice \& Society $;{ }^{9}$ departments were provided with extra copies to distribute among the staff.

(3) The campus personnel officer attended one session and explained how performance evaluations should be constructed. He talked about the necessity for making comprehensive evaluations during the first months of the probationary year, and the importance of stating precisely and clearly those areas in which improvements would be required before the granting of tenure.

(4) We read "Getting Along With Your Boss" from Lester R. Bittel's book What Every Supervisor Should Know, ${ }^{10}$ and that program included a discussion of the supervisor's dual role; a department head supplied information on "what the Department Head expects from the supervisor," and a student assistant discussed "what the subordinate expects from the supervisor."

(5) The library's systems analyst took three sessions in three successive weeks to teach the supervisors the technique of flow charting. Each supervisor actually prepared a flow chart of a simple operation.

(6) The California State Personnel Board supplied booklets on performance appraisal and evaluation, sick leave administration, and position classification.

The point to be made here, however, is not that these citations are the best available for a supervisory training program. The point is that if you furnish a group such as this with broad theory which is controversial and thought provoking, the group itself will begin to develop the program to be followed. As they talk about problems in their own areas, those subjects needing study become obvious. As each need developed, we were able to supply material to cover that subject; sometimes in the form of journal articles, sometimes a chapter from a book, sometimes an outside speaker with a particular expertise.

Probably the most valuable information of all comes from their contacts with each other. As Supervisor "A" begins to describe a particular personnel problem, the others begin to probe the various aspects of the situation and offer suggestions and possible solutions. Supervisor "B" talks about a problem area that exists between one of her subordinates and a subordinate of Supervisor "C." They agree to get together after the class is concluded to discuss the problem further. This contact and interaction with each other is probably of more value than all of the articles and speakers that could be provided by the program coordinator. This is one reason that the group should remain small and informal.

One year after the program began, a survey of effectiveness was made. Questionnaires were sent to the participants, their department heads, and their subordinates in an attempt to assess the value of the program. The key questions in all three questionnaires were designed to find out what the overall effect of the program had been on the department, whether people felt that the program should continue and, if so, what subjects should be included. As it turned out, the survey brought to light a variety of interesting facts. The first thing we learned was that we had made a giant error in the beginning, when the program was established, by not thoroughly explaining to the staff what the program was all about; what its purpose was, how people were selected to attend, what subjects were being explored. Also, the department heads should have played a greater role in setting up the program, particularly in terms of the amount of time to be spent in meetings and in keeping them informed of the subjects to be included. We made an incorrect assumption in the beginning that 
led to some bad feelings about the program. We assumed that supervisors attending the meetings would talk with their department heads about the subjects that were being discussed and that they would also pass some of it along to other members of the staff whom it would benefit. In some cases this did take place, but we found that other supervisors were not even informing their department head as to when the meetings were to take place. They simply disappeared at the appointed time and when the department head asked "Where is Susie?" one of her clerks would inform her that Susie had gone off to a supervisors' meeting. Furthermore, when Susie returned she tucked her notes and her handouts away in her desk without a word to anyone. In this case it was impossible for either the department head or the staff to assess the program. This will be corrected in the future by sending all announcements of meetings and all printed materials handed out to both the supervisor and the department head. Also, the supervisors will be reminded regularly that they must share their knowledge with others. The effect of this lack of communication was obvious when the results of the questionnaires were reviewed. While the morale of the supervisors was considerably improved by the experience, the members of the staff who responded were evenly divided on the question of whether or not the morale of the department had been improved. A sizeable percentage of the staff didn't respond to the questionnaire at all because they felt that they were not well enough informed to comment. The lesson to be learned here is that whenever you undertake such a program, be certain that your channels of communication are open and working, for no one likes to be ignored.

On the positive side, the department heads and the participants felt that the program was successful and should be continued. They felt that more decision making was occurring at lower levels, that less time was required by the department heads for training on an individual basis, and that communications both vertically and laterally had been improved. They also felt that, as a result of the program, the supervisors have a better understanding of a supervisor's role and that they have gained information to assist them with specific problems as well as information that will help them to avoid problems in the future. Even the majority of the staff responding to the questionnaire felt that the program should continue, in spite of the fact that some of them felt somewhat resentful at being left out.

A number of benefits were realized from the program including some very significant advantages gained by the library administration. For example, it has opened new channels of communication between the departments and the administration, bringing an increased sensitivity on the part of the administration to departmental problems. Additionally, artificial walls dividing similar functions being performed in different departments have partially disappeared, and the entire range of problems within the organization seems to have diminished.

Certainly the overall response to the program has been positive and the series will continue. Suggestions made by the respondents have been most helpful and will, whenever possible, be incorporated into future meetings. Staff and supervisors alike felt that more attention should be given to specific real problems being faced by supervisors. The need for more emphasis on decision making by supervisors was mentioned by the participants as well as department heads, and all three groups felt a need for the same type of program to be established for lower level supervisors; that is, supervisors of small numbers of student assistants. At this point in time it seems 
certain that a series will be planned for lower level supervisors covering much of the material of the first series. The upper level supervisors will continue to meet and discuss specific problems and we will develop a variety of topics as needs arise.

One may conclude that the need for supervisory training at the California State University, Northridge, Library is felt at all levels and that administrative efforts on behalf of such a program are greatly appreciated by the majority of those involved. Keep in mind, however, that if you plan to institute such a program in your library, you should take the time to carefully explain to the staff what your goals are and what your methods are to be so that you will not lose support that is important to the success of the total program.

\section{REFERENCES}

1. Douglas McGregor, The Human Side of Enterprise (New York: McGraw-Hill Book Company, Inc., 1960), p. 33-57.

2. John J. Morse and Jay W. Lorsch, "Beyond Theory Y," Harvard Business Review, 47: 61-68 (May-June 1970).

3. Robert Townsend, Up the Organization (New York: Knopf, 1970), p. 137-43.

4. Maxine Bishop, Dynamic Supervision; Problems \& Opportunities (New York: American Management Association, 1969), p. $124-48$.

5. Frederick Herzberg, Work and the Nature of Man (Cleveland: World Publishing Co., 1966), p. 95-96.

6. Frederick Herzberg, Motivation through Job Enrichment (motion picture produced by the Bureau of National Affairs, Inc., 1967).

7. Richard Magee, "The Employment Interview-Techniques of Questioning," in The Employment Interview-Techniques in Questioning (Pennsylvania: The Personnel Journal, Inc., 1969), p. 1-5.

8. Frank Gray, "How to Size Up People," in The Employment Interview-Techniques in Questioning (Pennsylvania: The Personnel Journal, Inc., 1969), p. 11-15.

9. Earl Roat and Seymour M. Lipset, Prejudice and Society (New York: Anti-Defamation League of B'nai B'rith, 1968).

10. Lester R. Bittel, What Every Supervisor Should Know (New York: McGraw-Hill, 1968) p. 507-15. 